\title{
Coaxial Control of Injection Equipments by Master Slave Scheme for a Parallel Speed Control System
}

\author{
Kiyoshi OchiＭember (kiyoshi_ochi@hiro.jsw.co.jp) \\ Masami SaekiＭember（saeki@hiroshima-u.ac.jp)
}

Keywords: injection molding machine, ball screw, servo motor, master slave, parallel speed control

A drive mechanism using servo motor and ball screw is applied to various industrial machines and it spreads quickly also as a drive mechanism of a plastic injection molding machine in recent years. In a large-sized machine, since big output was required, although the drive system by oil pressure was in use, an electromotive machine has come to be called for by the demand expansion of energy saving. Moreover, as a technical background, the large-sized electric servo system is becoming in practical use by the technical innovation of the power electronics that apply semiconductor.

However, when a ball screw with large diameter is used, there is a problem that rotation speed cannot be made high by the restrictions on the value of $\mathrm{dN}$. Therefore, in order to obtain a desired injection speed, it will be necessary to combine a byway ball screw with small diameter. For this reason, each company has been developing the technique of synchronizing drives for plurality axes to meet the increase of large output power. This is a parallel load sharing problem. In this paper, we consider the parallel control system shown by Fig. 1.

Although the parallel drive mechanism of a ball screw is applied not only to an injection molding machine but also to various

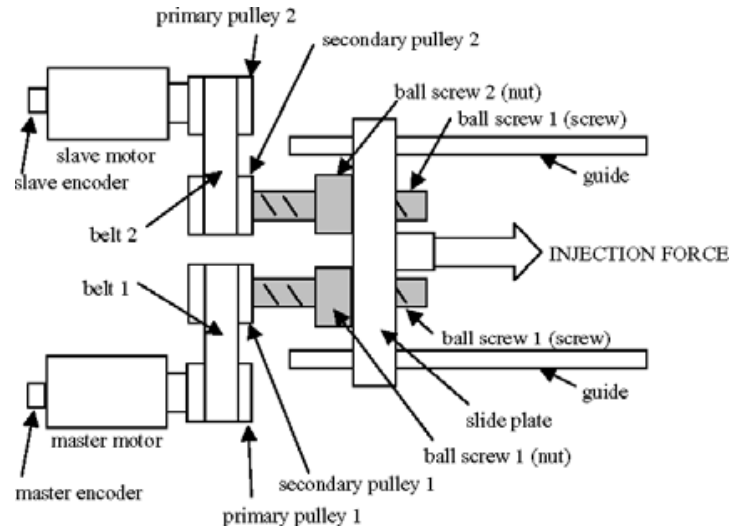

Fig. 1. Parallel control system industrial machines, a difficult point for the drive mechanism of an injection molding machine, compared with other applicable fields, is that severe load conditions are imposed especially on a ball screw. A ball screw roll fundamentally changes the torque of a servo- motor into the thrust for a straight-line motion by friction. On such conditions, it becomes impossible to exhibit the original transfer efficiency of a ball screw, and nonlinear friction inside a ball screw will be increased enormously. Therefore, in transmitting the driving force with two or more ball screws, consideration which does not generate the imbalanced state of ball screw load is necessary.

In this paper, a novel master-slave system is proposed for the coaxial control of injection equipments shown by Fig 2. Each axis is basically controlled by the PI speed control system and a new master-slave scheme is introduced for the coaxial control of the angles of the two parallel subsystems. The adequacy of the scheme is supported by the controllability of the system. Easiness of the parameter tuning of the controller is clarified from the viewpoint of stability, tracking property, and disturbance rejection property. Simulation result and experimental result are also given for the test equipment.

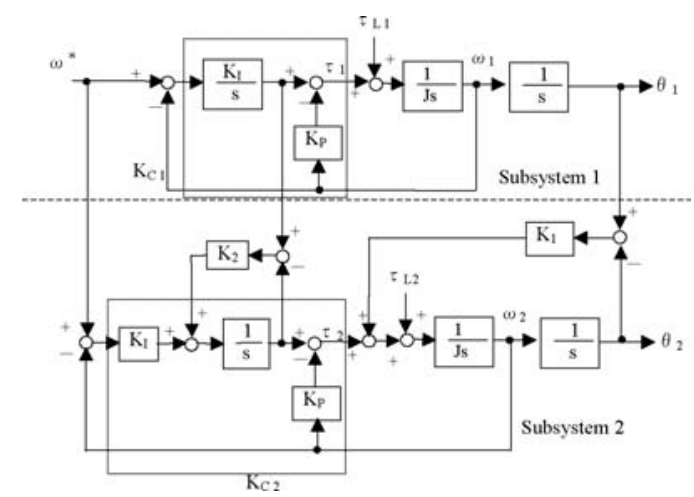

Fig. 2. Proposed control structure 


\title{
速度制御系をベースとした \\ マスタースレーブ方式による射出装置の同軸制御
}

\author{
正員 越智 清史* 正 員 佐伯 正美**
Coaxial Control of Injection Equipments by Master Slave Scheme for a Parallel Speed Control System

Kiyoshi Ochi*, Member, Masami Saeki**, Member

\begin{abstract}
In this paper, a novel master-slave system is proposed for the coaxial control of injection equipments constituted with two or more drive axes. Each drive axis is basically controlled by the PI speed control system and a new master-slave scheme is introduced for the tracking control of the angles of the two parallel subsystems. The adequacy of the scheme is supported by the controllability of the system. Easiness of the parameter tuning of the controller is clarified from the viewpoint of stability, tracking property, and disturbance rejection property. Simulation result and experimental result are also given for the test equipment.
\end{abstract}

キーワード：射出成形機，ボールねじ，サーボモータ，マスタースレーブ，並列速度制御

Keywords: injection molding machine, ball screw, servo motor,master slave, parallel speed control

\section{1. はじめに}

サーボモータ及びボールねじを用いた駆動システムは, 工作機械やロボット等様々な産業機械に適用が進んでおり, 近年，プラスチック射出成形機の駆動システムとしても普 及拡大している。数年前までは, 射出成形機の駆動装置は, 油圧を駆動源とするシステムが主流であったが，サーボモー タとボールねじによる駆動システムへ急速に駆動方式が移 行した。この背景として, サーボモータを利用することに よる, 省エネルギー効果, 油を利用しないことによるクリー ン性及び生産設備としての設置の容易さが挙げられる。ま た，技術的には，特にパワーエレクトロニクスの技術革新 があり，IGBT 等利用しやすいパワーデバイスが普及した こと，さらには高性能マイコンを安価に利用できるように なったことなどが挙げられる。

しかしながら，ボールねじを使用した駆動方式で大型化 を図ろうとすると, 大きな出力を得るために, 大径ボール ねじが必要となるが, $\mathrm{d} \times \mathrm{N}$ 值 $(\mathrm{d}$ ：ボールねじの径, $\mathrm{N}$ ：回

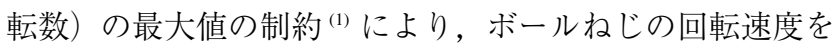

\footnotetext{
* (株) 日本製鋼所 広島製作所

干736-8602 広島市安芸区船越南 1-6-1

Japan Steel Works, LTD, Hiroshima Plant

1-6-1, Hunakoshi-minami, Aki-ku, Hiroshima 736-8602

** 広島大学大学院工学研究科

干 739-8527 東広島市鏡山 1-4-1

Graduate School of Engineering, Hiroshima University

1-4-1, Kagami-yama, Higashihiroshima 739-8527
}

高くできないという問題がある。また，リニアモー夕等の 回転一直線変換機構を使用しない駆動方式も小容量な機械で は実現されているが，大きな推力を得ることが困難であり， 大型の機械に対しては，ボールねじを使用した機構が今後 も主流であると考えられる。このような理由により，射出 成形機メーカは，小径ボールねじを組み合わせた駆動技術 の開発を行っている。これは, 複数の駆動軸の合力を共通 の軸出力として得るという目的から, 並列負荷分担制御問 題 (2)であるといえる。

ボールねじの並列駆動メカニズムは，射出成形機だけで なく様々な産業機械に適用されている。しかしながら，他 の応用 ${ }^{(3)(4)}$ と異なる点は, 射出成形機では, 射出工程や保 圧工程で厳しい負荷条件がボールねじに課されるために, ボールねじ本来の伝達効率を得ることが困難であり, ボー ルねじ内部の非線形摩擦の影響が大きいことである。そこ で，2つ以上のボールねじを並列駆動する場合には，それ らの影響によりボールねじの負荷がアンバランスな状態に ならないような考慮が必要である。

また，射出装置の動作は，速度制御，位置制御，圧力制 御の 3 つの制御モードで実現されているが，非線形摩擦の 影響などを抑制するためには速度制御系をマイナーループ として構成することが望ましい。そこで, 並列駆動システ ムにおいても, 各軸を速度制御し, それをべースとして各 制御モードを構成するのがシステム設計上好都合である。

本論文では，2つのボールねじ駆動による射出装置に対 し，速度制御系をべースとした同軸制御問題を検討し，マス 


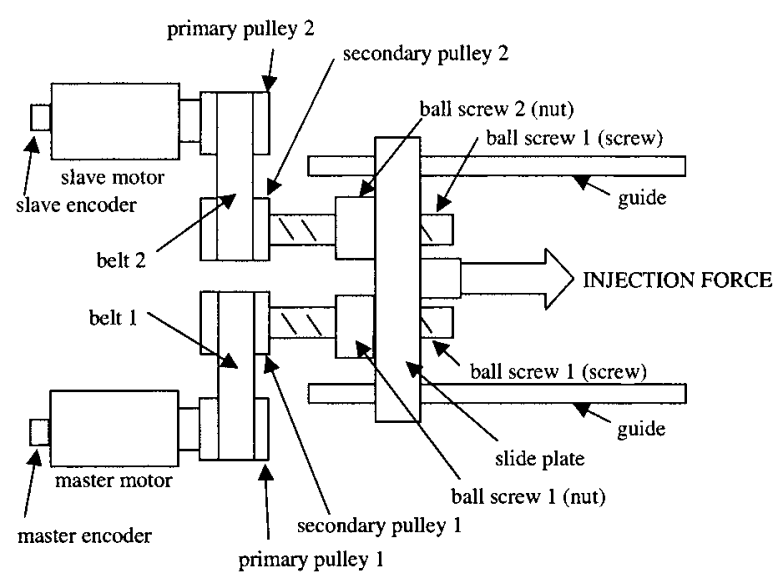

図 1 並列駆動システムの構成

Fig. 1. Parallel drive system.

タースレーブ方式による新しい並列駆動制御システムを提 案する。提案するアルゴリズムによれば，マスターとなる 速度制御系に並列に構成されたスレーブの速度制御系に対 し, 角度誤差の追従制御と速度制御積分器の追従制御を付 加することによって，速度制御系をべースとしたマスター スレーブシステムの構成が可能となる。この方式によれば, 各駆動軸の動作バランスを維持しながら複数軸の速度制御 を行うことができるというメリットが得られる。このシス テムに対し, 安定性や外乱応答特性を解析し, シミュレー ションと実験により有効性を検証する。

\section{2. システムの定式化}

$\langle\mathbf{2} \cdot \mathbf{1}\rangle$ 並列駆動機構のモデル 2 軸並列駆動の射出装 置の構成を図 1 に示す。各駆動軸は完全に対称なパーツで 構成されている。本論文では，同軸制御のアルゴリズムの 解析と設計に重点をおいているため, 各駆動軸のモデルは 次に示すような単純な 1 慣性系として表現することとする。 また，対称構造であることより，それぞれの慣性モーメン

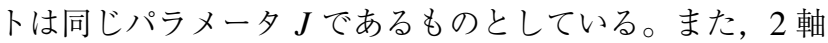
間の力学的干渉を考慮したモデルも考えられるが, 本論文 では，2 軸間の角度および駆動トルクのアンバランスを生 じさせる要因を，干渉の影響も含めて，次式のように外乱 トルク $\tau_{L i}$ に集約して表している。

$$
\begin{gathered}
J \frac{d \omega_{i}}{d t}=\tau_{i}+\tau_{L i} \ldots \\
\frac{d \theta_{i}}{d t}=\omega_{i},(i=1,2) \\
\tau_{L i}=\frac{F}{2}+\delta_{i} \ldots \ldots
\end{gathered}
$$

$\theta_{i}:$ サーボモー夕の回転角度

$\omega_{i}$ : サーボモータの回転角速度

$\tau_{i}:$ サーボモータのトルク

$\tau_{L i}:$ 外乱トルク

$J$ ：モー夕軸換算全イナーシャ

$i:$ 駆動軸番号

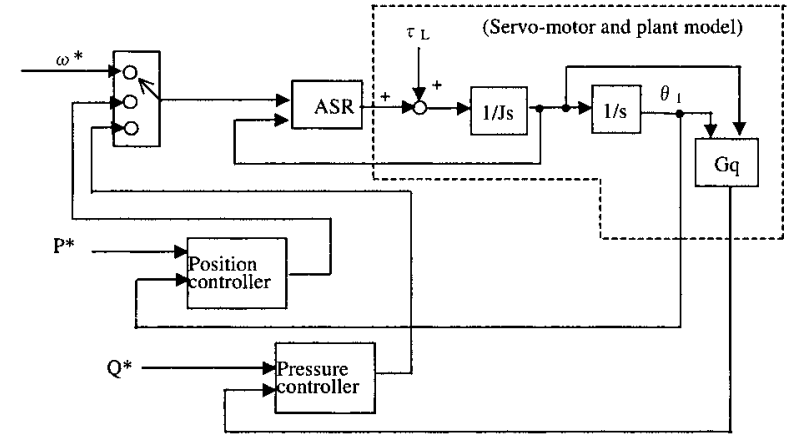

図 2 射出装置の制御

Fig. 2. Control block for the Injection unit.

\section{$F: 2$ 軸の合力として得られる射出力}

$\delta_{i}:$ 各軸の摩擦㧍よび軸間の干渉成分

それぞれの駆動軸は，駆動源としてのサーボモー夕，減 速比を得るための夕イミングベルトおよびプーリ，抢よび モータの駆動トルクを直線方向への推力に変換するボール ねじから構成されている。2つのボールねじによって得ら れる推力は，共通のスライドプレートに与えられ，2 軸の 合力として射出力が得られる。この推力は射出スクリュの 推力となり，樹脂を金型に瞬時に注入するための射出圧力 となる。正確には，それぞれの駆動システムの特性は，夕 イミングベルトにより結合された 2 慣性系としてモデル化 されるべきであるが，先に述べたように，アルゴリズムの 解析を容易にするために一慣性系としている。

各軸の位置関係が平行に保たれている場合，基本的に各 軸は $\frac{1}{2} F$ ずつ均等に分担している。しかし，駆動トルクか ら推力までの伝達機構としては, タイミングベルト, プー リー，ボールねじ，スライドプレートがあり，無視できな い内部損失が存在している。特に，回転力を直線方向への 推力に変換するボールねじは, 過大な負荷を受けながら動 作する場合の内部損失（摩擦）が無視できない。このよう な内部摩擦力は, 各軸において均等である保証はなく, ア ンバランスな位置関倸で動作した場合，特にボールねじの 寿命に大きく影響を与えることになる。

$\langle\mathbf{2} \cdot 2\rangle$ 射出装置の制御射出軸の動作は，主に溶融 樹脂を金型に注入する射出工程，樹脂圧力を一定に保つ保 圧工程, 工程完了後の位置保持工程から成り立っている。 これらは，図 2 に示すように，3つの制御モード（速度制 御・圧力制御・位置制御）によって達成される。また, 射出 軸の制御においては，いずれの制御モードにおいても速度 制御をマイナーループに備えることが望ましいと考えられ る。その理由としては，ボールねじを使用したシステムで あるため, 機構内部に存在する非線形摩擦の影響を受けな いシステムを構成することにある。すなわち, 速度フィー ドバック制御を構成することによって，非線形摩擦の影響 を，速度制御系の特性として吸収し，線形なシステムとし て全体の制御系を構築することができる。破線で囲まれた 部分は制御対象であり， $\tau_{L}$ は外乱トルク，Jは駆動系のイ 
ナーシャ, $\theta_{1}$ は駆動軸の回転角度, $G_{q}$ は, 圧力制御系の 伝達関数を表している。ASR は速度制御器であり, セレク タスイッチによって, 速度制御モードの時は, 速度指令 $\omega^{*}$ に対する速度制御が実行される。また，他の制御モードと して位置制御器（position controller）および，圧力制御器 (pressure controller) を備え，それぞれ，圧力指令 $P^{*}$ ，位 置指令 $Q^{*}$ の指令に対して制御演算を行い, 制御出力とし て, ASRへの速度指令を発生している。

〈2·3〉速度制御系をべースとしたマスタースレーブ構造

前節で述べたように，射出軸の制御においては，並列駆 動となった場合でも，1軸の場合と同様，速度制御系をべー スとした構成の方が，全体の制御構成を考えた場合に，シ ステムの扱いが容易となる。また，各軸が 1 軸の場合と同 等な速度制御システムとして設計できれば，制御系の設計 もより容易なものになると考えられる。従って, 我々はま ず，図 3 のような，独立した同一方式の速度制御系を複数 軸並列動作させる方式を検討することとした。

図 3 に示すように，各コントローラには同一の速度指令 $\omega^{*}$ が与えられており，各軸はそれぞれ独立した速度フィー ドバック制御器 $K_{C 1}, K_{C 2}$ を備えている。本システムでは, 比例積分 (PI) 制御器としている。この場合の各軸に対す る回転角速度指令としての目標值入力 $\omega^{*}$ から, 出力 $\omega$ ま での閉ループ伝達関数は次式で表される。

$$
g_{i}(s)=\frac{K_{I} / J}{s^{2}+\left(K_{p} / J\right) s+K_{I} / J}
$$

ここに，

\section{$K_{P}:$ 速度制御比例ゲイン \\ $K_{I}$ : 速度制御積分ゲイン}

である。各軸の回転角度 $\theta_{1}, \theta_{2}$ は, 各軸の回転角速度 $\omega_{1}$, $\omega_{2}$ の積分結果として得られるが，図 3 に示すように各軸 にはそれぞれ外乱トルク $\tau_{L 1}, \tau_{L 2}$ が存在しており, 角度 差 $e_{1}=\theta_{1}-\theta_{2}$ が発生する。そこで， $e_{1}$ を小さくするため に， $e_{1}$ に基づいてスレーブの動作を補正するフィードバッ ク $\left(K_{1} e_{1}\right)$ がされている。しかし，このシステムには，次 に示す不可制御の問題が存在する。

〈2·4〉 スレーブ追従系の不可制御性 図 3 では，制 御器 $K_{1}$ によって $\theta_{2}$ が $\theta_{1}$ に追従するような制御系を構成し ている。この制御問題は, 図 4 のように入力が $u\left(=K_{1} e_{1}\right)$, 出力が $y\left(=\theta_{2}\right)$ のシステムで, 出力 $y$ を外部信号に追従さ せる問題と考えることができる。ところで，このシステム の状態方程式は, 次の (5) 式，(6) 式で表されるが,

$$
\begin{aligned}
& \dot{x}=A x+B u \\
& y=C x \ldots
\end{aligned}
$$

ここに,

$$
\begin{aligned}
& x=\left[\begin{array}{lll}
x_{1} & x_{2} & x_{3}
\end{array}\right]^{T} \\
& A=\left[\begin{array}{ccc}
0 & 1 & 0 \\
0 & -\frac{K_{p}}{J} & \frac{1}{J} \\
0 & -K_{i} & 0
\end{array}\right], B=\left[\begin{array}{c}
0 \\
\frac{1}{J} \\
0
\end{array}\right]
\end{aligned}
$$

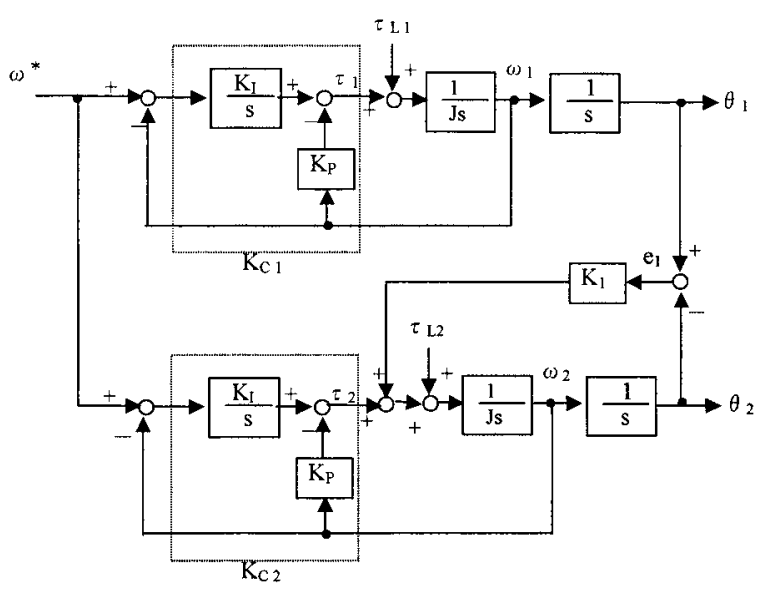

図 3 速度制御ベース並列構造

Fig. 3. Parallel control structure based on speed control system.

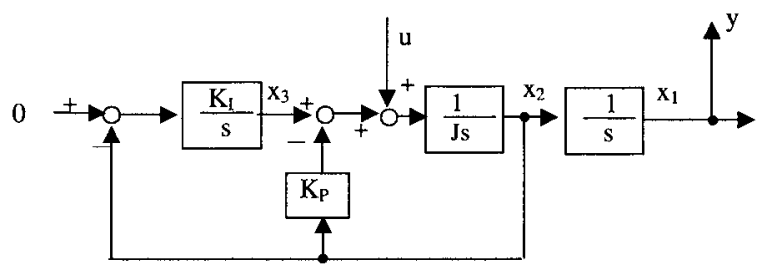

図 4 不可制御性を内在するスレーブ追従系

Fig. 4. Slave control block including uncontrolability.

$$
C=\left[\begin{array}{lll}
1 & 0 & 0
\end{array}\right]
$$

であり，可制御性行列 $U_{c}$ は，

$$
\begin{aligned}
& U_{c}=\left[\begin{array}{ccc}
0 & 1 / J & -K_{p} / J^{2} \\
1 / J & -K_{p} / J^{2} & K_{p}^{2} / J^{3}-K_{i} / J^{2} \\
0 & -K_{i} / J & K_{i} K_{p} / J^{2}
\end{array}\right] \ldots \ldots \ldots \\
& \operatorname{det}\left[U_{c} J^{2}\right]=J^{2} K_{p} K_{i}-J^{2} K_{p} K_{i}=0 \ldots \ldots \ldots \ldots \ldots
\end{aligned}
$$

であるので，このシステムは不可制御である。これは， $x_{1}$ の積分要素と $x_{3}$ の積分要素が制御入力 $u$ から見て並列に接 続されていることから生じており，これは $x_{1}$ と $x_{3}$ を独立 に制御できないことを意味している。これにより，状態変 数 $x_{2}$ のフィードバック経路, すなわち速度検出值のフィー ドバックに測定雑音などの外乱が含まれる場合には，uで 制御しても $y$ を外部信号に追従させることはできない。観 測ノイズとしては，実システムにおいてパルスエンコーダ を使用した場合には, 有限分解能のパルス数から, サンプ リング間隔毎の速度平均值を算出する際のソフト処理上の 誤差があり, また, センサ構造に起因する問題としては, ス リットディスクの偏芯や面振れ，スリットピッチ誤差等が ある ${ }^{(5)}$ 。そこで, この不可制御の問題を解決するために, ス レーブコントローラの積分器 $K_{I} / s$ へ入力を追加するこ とが必要となる。

〈2·5〉提案する制御構造前節の不可制御性の考察 より， $x_{3}$ の積分器の入力側に新たに制御入力を追加すれば $x_{3}$ が可制御にできる。実際，この 2 入力システムの可制御 
性行列 (省略) はフルランクとなる。一方，われわれの目 的とするシステムは，速度制御をベースとした並列制御シ ステムの構築である。従って，システムの対称動作を重視 すべきと考え, 積分器への制御入力の与え方として図 5 の 方式を提案する。すなわち，マス夕の速度制御積分器出力 とスレーブの速度制御積分器出力との誤差 $e_{2}$ を，スレーブ の積分器に, 制御器 $K_{2}$ を介してフィードバックする方式 を提案する。

破線の上側のサブシステム 1 が基準システムとしてのマ スターに，下側のサブシステム 2 が追従系としてのスレー ブに相当している。本論文においては，各制御器 $K_{1}$ およ び $K_{2}$ は，次式によって構成するものとする。

$$
\begin{aligned}
& K_{1}=\alpha \cdots \\
& K_{2}=\frac{\gamma}{T s+1}
\end{aligned}
$$

制御器 $K_{1}$ を導入する方式は, 回転角度の追従制御系を構成 する方式として，一般的に使用される手法であるが(6)，制 御器 $K_{2}$ を備えるマスタースレーブシステムは，著者の知 る限りユニークな制御構造であると考える。我々の問題は, $K_{1}$ および $K_{2}$ を設計することであり，このシステムは次の 条件を満足する必要がある。

条件 1: 目標值 $\omega^{*}$ に対して望ましい応答が得られること。 条件 2: 外乱トルク $\tau_{L 1}$ および $\tau_{L 2}$ に対し, 制御偏差 $e_{1}$ および $e_{2}$ が速やかに収束すること。

\section{3. システム特性の解析}

前節で提案した図 5 のシステムは，設計パラメータとし て， $K_{P}, K_{I}, \alpha, T$, および $\gamma$ を有しており, 我々は, こ れらのパラメータと安定性，目標值応答および外乱抑制特 性，さらにパラメータの調整範囲について検討する。

〈3・1〉安定性図 5 のシステムにおいて, システ ムのアンバランスを生じさせる要因は， $\tau_{L 1}$ および $\tau_{L 2}$ であ るため，外乱に着目した $\left(\omega^{*}=0\right.$ とした $)$ 図 6 のシステム を考える。このシステムは，次式で表される。

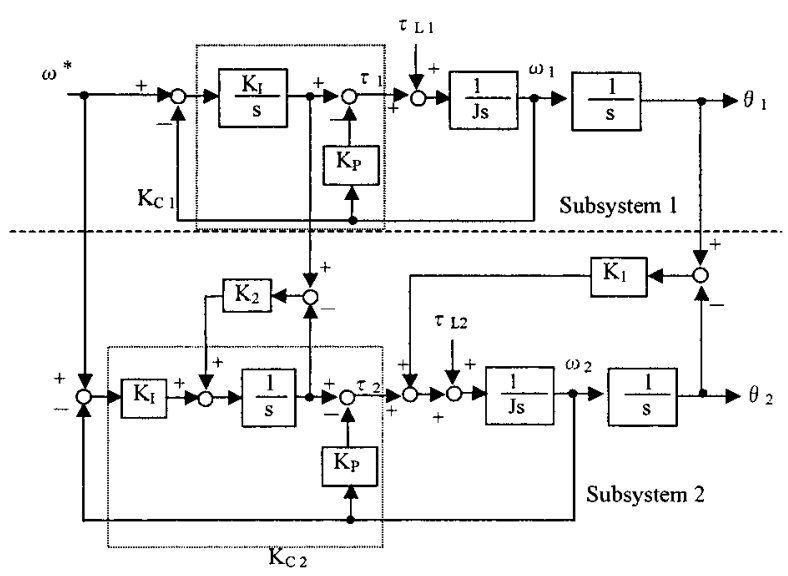

図 5 提案する制御構造

Fig. 5. Proposed control structure.

$$
\begin{aligned}
& y_{1}=\frac{1}{J_{S}}\left(\tau_{L 1}-K_{P} y_{1}-\frac{K_{I}}{s} y_{1}\right) \ldots \\
& u_{1}=\frac{K_{I}}{s} y_{1} \\
& u_{2}=\frac{1}{s}\left(K_{I} y_{2}+\frac{\gamma}{1+T s}\left(u_{1}-u_{2}\right)\right) \\
& e_{1}=\frac{1}{s}\left(y_{1}-y_{2}\right) \\
& e_{2}=u_{1}-u_{2} \\
& y_{2}=\frac{1}{J s}\left(\tau_{L 2}+\frac{\alpha}{s}\left(y_{1}-y_{2}\right)-u_{2}-K_{P} y_{2}\right)
\end{aligned}
$$

(11) 式〜(16) 式より, サブシステム 1 の特性多項式 $\phi_{1}$ と サブシステム 2 の特性多項式 $\phi_{2}$ を導出すると次式を得る。

$$
\begin{aligned}
\phi_{1}(s)= & s^{2}+\frac{K_{P}}{J} s+\frac{K_{I}}{J} \cdots \cdots \ldots . \\
\phi_{2}(s)= & J T s^{4}+\left(J+K_{P} T\right) s^{3} \\
& +\left(J \gamma+\alpha T+K_{I} T+K_{P}\right) s^{2} \\
& +\left(\alpha+K_{I}+K_{P} \gamma\right) s+\alpha \gamma \cdots
\end{aligned}
$$

本システムは, マスタースレーブシステムであり, サブシ ステム 1 とサブシステム 2 の直列構造になっている。従っ て, 全体システムの特性方程式は $\phi_{1}(s) \phi_{2}(s)=0$ で表され, 安定条件は, $\phi_{1}$ と $\phi_{2}$ がいずれも安定な多項式であること である。 $\phi_{1}$ の安定条件は, $K_{P} / J>0, K_{I} / J>0$ である。 ここでは, $\phi_{2}(s)=0$ の安定性について調べる。ラウスフル ヴィッツの安定条件より, 次の必要十分条件を得る。

$$
\begin{aligned}
& J T>0, J+K_{P} T>0, \\
& J \gamma+\alpha T+K_{I} T+K_{P}>0, \\
& \alpha+K_{I}+K_{P} \gamma>0, \alpha \gamma>0, \\
& K_{P}(J \gamma-T \alpha)^{2} \\
& \quad+\gamma\left(J^{2} K_{I}+J K_{P}^{2}+K_{P}^{2} K_{I} T^{2}+K_{P}^{2} T\right) \\
& \quad+\alpha\left(K_{P} K_{I} T^{2}+J K_{P}+K_{P} K_{I} T^{2}+K_{P} T\right) \\
& \quad+\left(J K_{P}+K_{P} K_{I} T^{2}+K_{P}^{2} T\right) K_{I}>0
\end{aligned}
$$

$\phi_{1}$ の安定性より，

$$
J>0, K_{P}>0, K_{I}>0
$$

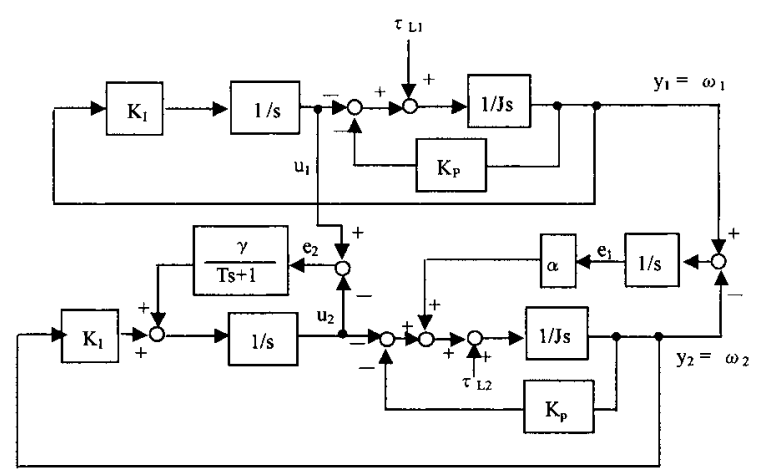

図 6 外乱特性解析のためのブロック図

Fig. 6. Block diagram for analyzing disturbance characteristics. 
であり，さらに調整パラメータを

$$
T>0, \alpha>0, \gamma>0
$$

と選ぶことによって上記の不等式が満たされるので，この ようにパラメータを選ぶことで， $\phi_{2}(s)$ の安定性が常に保証 される。これはゲイン調整にとって都合の良い性質である。

$\langle\mathbf{3} \cdot 2\rangle$ 目標値応答特性 目標值 $\omega^{*}$ から $y_{i}\left(=\omega_{i}\right) へ の$ 望ましい伝達特性を,

$$
y_{i}=g_{i}(s) \omega^{*}
$$

ここに,

$$
g_{i}(s)=\frac{\omega_{n 1}^{2}}{s^{2}+2 \zeta_{1} \omega_{n 1} s+\omega_{n 1}^{2}}
$$

とすると，PI ゲインは次式によって決定される。

$$
\begin{aligned}
& K_{I}=J \omega_{n 1}^{2} \cdots \\
& K_{P}=2 \zeta_{1} \omega_{n 1} J
\end{aligned}
$$

ここに， $\omega_{n 1}$ は速度制御系の角周波数， $\zeta_{1}$ は速度制御系の 減衰係数である。2つのサブシステムが完全に同期した場 合, 各システムは (19) 式のように応答し， $K_{1}$ 及び $K_{2}$ は動 作せず，望ましい目標值応答が得られる。

一方, 速度制御積分器のバランスを調整する制御器 $K_{2}$ は， $u_{2}$ が $u_{1}$ にすみやかに追従するように，動作するよう 設計されることが望ましい。 $u_{1}$ から $e_{2}$ への伝達特性は,

$$
e_{2}=\frac{s(T s+1)}{T s^{2}+s+\gamma} u_{1}
$$

であるので, $T$ と $\gamma$ は, 望ましい角周波数 $\omega_{n 2}$ と減衰係数 呅に対して，次のように選ばれるべきと考える。

$$
\begin{aligned}
& T=\frac{1}{2 \zeta_{2} \omega_{n 2}} \\
& \gamma=\frac{\omega_{n 2}}{2 \zeta_{2}} \cdots
\end{aligned}
$$

$\langle\mathbf{3} \cdot \mathbf{3}\rangle$ 外乱抑制特性 外乱トルク $\tau_{L 1}, \tau_{L 2}$ が，アン バランス評価量としての $e_{1}, e_{2}$ へ与える特性について考察 する。 $\tau_{L 1}$ から $y_{1}$ および $u_{1}$ への伝達関数として, (11) 式 および (12) 式より次式を得る。

$$
\begin{aligned}
& y_{1}=\frac{s}{J \phi_{1}(s)} \tau_{L 1} \\
& u_{1}=\frac{K_{I}}{J \phi_{1}(s)} \tau_{L 1}
\end{aligned}
$$

さらに，(13) 式，(16) 式より，

$$
\begin{aligned}
u_{2}= & \frac{K_{I}(1+T s)}{T s^{2}+s+\gamma} y_{2}+\frac{\gamma}{T s^{2}+s+\gamma} u_{1} \\
y_{2}= & \frac{s\left(T s^{2}+s+\gamma\right)}{\phi_{2}(s)} \tau_{L 2} \\
& +\frac{\alpha\left(T s^{2}+s+\gamma\right)}{\phi_{2}(s)} y_{1}-\frac{\gamma s}{\phi_{2}(s)} u_{1}
\end{aligned}
$$

（26）式，(27) 式，(29) 式を(14) 式に代入し，整理すると， $\tau_{L 1}, \tau_{L 2}$ から $e_{1}$ への伝達関数は次式となる。

$$
e_{1}=\frac{T s^{2}+s+\gamma}{\phi_{2}(s)}\left(\tau_{L 1}-\tau_{L 2}\right) .
$$

同様に，(26) 式，(27) 式，(28) 式，(29) 式を (15) 式に代 入すると, $\tau_{L 1}, \tau_{L 2}$ から $e_{2}$ への伝達関数は次式となる。

$$
e_{2}=\frac{K_{I}\left(T s^{2}+s\right)}{\phi_{2}(s)}\left(\tau_{L 1}-\tau_{L 2}\right) .
$$

(30) 式，(31) 式の導出は付録に述べる。

これらの式の特徴として, 外乱から偏差への影響は符号 を除いて, 同じ值を持ち, $\phi_{1}(s)$ は式に現れない。また, 次の 伝達関数のゲイン特性を描くことによって, 角度誤差 $e_{1}$ と トルク誤差 $e_{2}$ に対する外乱の影響がそれぞれ評価される。

$$
\begin{aligned}
& g_{e 1}(s)=\frac{T s^{2}+s+\gamma}{\phi_{2}(s)} \\
& g_{e 2}(s)=\frac{K_{I}(T s+1) s}{\phi_{2}(s)}
\end{aligned}
$$

さらに，単位ステップ外乱に対する定常偏差は次式で表さ れる。

$$
\begin{aligned}
& e_{1}(\infty)=\frac{1}{\alpha}\left(\tau_{L 1}-\tau_{L 2}\right) \\
& e_{2}(\infty)=0 \ldots \ldots \ldots
\end{aligned}
$$

安定性と定常偏差の条件から， $\alpha$ は大きくするほど良いと いう傾向が言えるが，過渡応答やモデル誤差の影響を考慮 すれば，単純に $\alpha$ は大きくすれば良いとは言えない。そこ で実際のシステムにおいては, 定常偏差条件で決定される $\alpha$ を参考に調整を行うのが現実的と考える。

\section{4. シミュレーション及び実験による特性の評価}

〈4・1〉 テスト装置テスト装置としては，推力が約 $1000 \mathrm{kN}$ 程度のもので評価を行った。この推力は, 射出成 形機のクラスとしては, 大型家電製品のケース等の成形品 に対応できる推力であり，比較的大型のものである。以下 のシミュレーションでは, 制御パラメータは, 表 1 の諸元 に設定して評価を行った。

$\langle\mathbf{4 \cdot 2 \rangle}$ 外乱応答の計算 図 6 のシステムにおいて, 外 乱トルク $\tau_{L 1}$ に対する外乱応答について, 表 1 の数值を用 いて評価を行う。想定される外乱としては，ボールねじの 内部摩擦特性は, 推力に依存して非線形に増減する要素を 含んでいることから，ステップ外乱に対する評価を行うこ ととした。また，制御器 $K_{2}$ の導入に着目した解析に重点 を置いていることから，ここでは，外乱応答とパラメータ $\gamma$ の関係を調べる。 $\gamma=0.1,4,16,31.25,125$ に対して計算 を行い, 以下の計算において, 外乱トルク $\tau_{L 2}$ はゼロとし ている。

まず，単位ステップ外乱入力 $\tau_{L 1}$ に対する $e_{1}(t)$ 及び $e_{2}(t)$ のステップ応答を図 7 及び図 8 に示す。もし, $\gamma$ が非常に 小さい正数であれば, 偏差 $e_{1}$ 及び $e_{2}$ が定常状態 $e_{1}(\infty)$ 及 び $e_{2}=0$ に到達するのに長い時間がかかる。すなわち, シ ステムの過渡状態が長い時間継続することを意味している。 
表 1 テスト装置のパラメータ

Table 1. Parameters of test equipment.

\begin{tabular}{l|l}
\hline$J$ & $0.257\left[\mathrm{kgf} \cdot \mathrm{m}^{2}\right]$ \\
$K_{P}$ & $45.7[\mathrm{~N} . \mathrm{m} \cdot \mathrm{s} / \mathrm{rad}]$ \\
$K_{I}$ & $1024[\mathrm{~N} . \mathrm{m} \cdot \mathrm{s} / \mathrm{rad}]$ \\
$\alpha$ & $645[\mathrm{~N} . \mathrm{m} / \mathrm{rad}]$ \\
$T$ & $0.016[\mathrm{sec}]$ \\
$\gamma$ & variable value \\
\hline
\end{tabular}

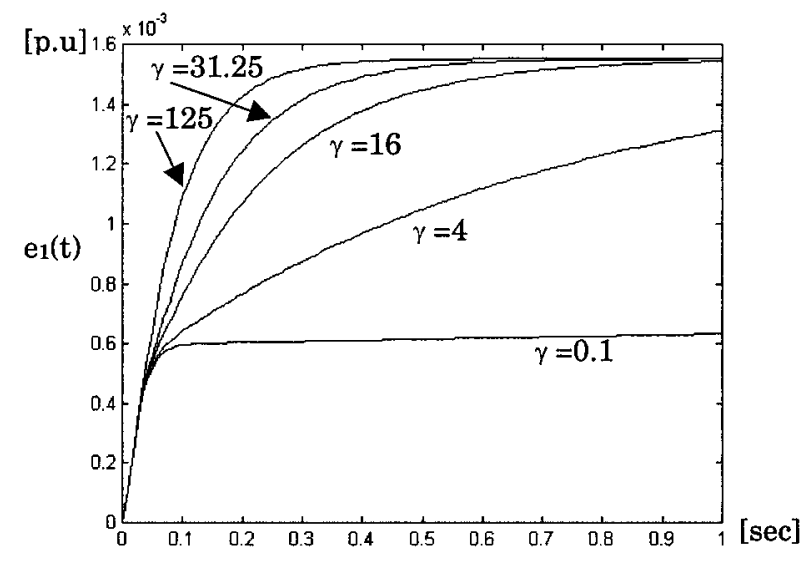

図 $7 e_{1}(t)$ のステップ応答

Fig. 7. Step response $e_{1}(t)$.

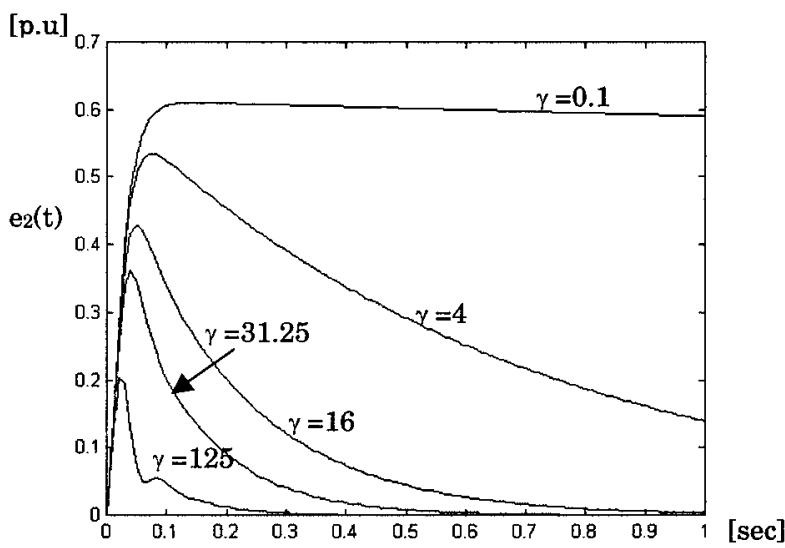

困 $8 e_{2}(t)$ のステップ応答

Fig. 8. Step response $e_{2}(t)$.

$\gamma$ がより大きくなるにつれ $e_{1}$ 及び $e_{2}$ の整定時間は短くな り, $e_{2}(t)$ のピークは小さくなる。これは, 各速度制御積分 器のバランスが， $\gamma$ を調整することによって，十分に調整 されることを示している。

次に, 角度誤差に対する $\gamma$ の影響について調べる。 $g_{e 1}(s)$ のゲイン特性を図 9 に示す。定常偏差 $e_{1}(\infty)$ は,

$$
e_{1}(\infty)=g_{1 e}(0)=\frac{1}{\alpha}
$$

によって決定され，この場合， $g_{1 e}(0)=1 / 645=-56[\mathrm{~dB}]$ である。 $e_{1}(\infty)$ は $\alpha$ ので決まり， $\gamma$ は影響しない。また， 図 9 において, ゲインの最大值，いわゆる $H_{\infty}$ ノルムは，全 ての $\gamma$ の值に対して， $-56[\mathrm{~dB}]$ 以下に維持されていること が分かる。これは, 全ての $\gamma$ の值に対して, $e_{1}(t)$ の $L_{2}$ ノル

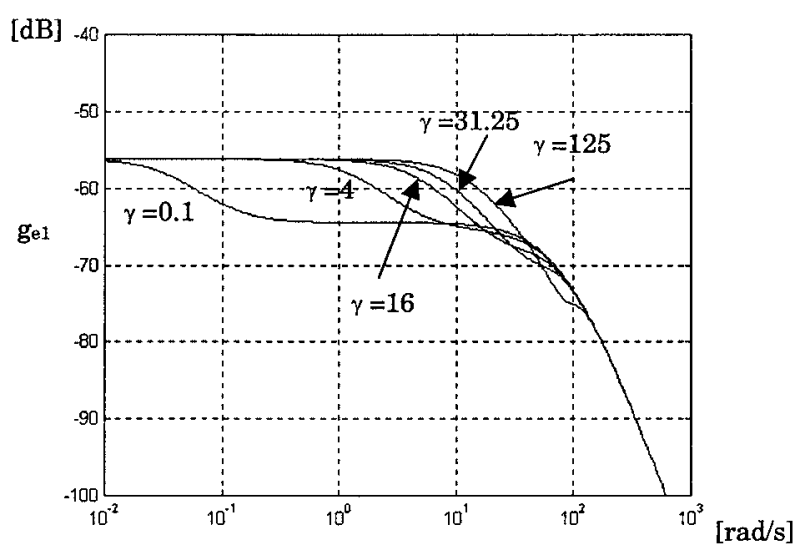

図 $9 g_{e 1}(s)$ の周波数応答

Fig. 9. Frequency gain response of $g_{e 1}(s)$.

ムが充分小さいことを意味している (7)。すなわち, $e_{1}(s)$ は， 主に $\alpha$ にって調整される。このパラメータ間の独立性に より， $\alpha$ 及び $\gamma$ のゲイン調整を容易に行うことができる。

$\langle\mathbf{4} \cdot \mathbf{3}\rangle$ 実験結果 実際の射出装置に対して実験を行っ た。装置パラメータおよび制御定数は, 表 1 の通りであり, $\gamma$ については, その効果を調べるため, 2 種類の設定につ いて評価を行った。また, シミュレーションでは, 負荷ト ルク外乱 $\left(\tau_{L 1}\right)$ に対する評価を行ったが，実際の装置にお いて，外乱トルクを与えること及び測定することは非常に 困難である。従って，実機テストにおいては，外乱を与え る代わりに, 加減速運転によって， $\gamma$ の効果を調べた。運 転パターンとしては，速度設定值 $\left(\omega^{*}\right)$ を，0 から $100 \%$ 速度 $(1.0[p . u])$ ヘランプ状に増加させた後, 定速運転し, その後 $10 \%$ 速度に減少後停止するように設定している。ま ず， $\gamma$ が小さい場合の評価として， $\gamma=0.3$ の場合について の実験波形を図 10 に示す。実験では, 速度設定值 $\omega^{*}$, 速 度応答 $\omega_{1}$, 角度差 $e_{1}$, 速度制御積分器誤差 $e_{2}$ を測定した。 図 10 の波形から, 最大角度差 $e_{1}$ は約 $5[\mathrm{deg}]$, 速度制御積 分器の最大誤差は約 0.08 [p.u] であり, 加減速期間全体に おいて, $e_{1}$ および $e_{2}$ の值が常にプラス側にオフセットして いることが分かる。このことは，すなわちマスター側の速 度制御積分器出力および角度が常に先行していることを示 している。一方, 図 11 は, $\gamma$ を大きくした場合の実験結果 である $(\gamma=31.25)$ 。加速時には $e_{2}$ が増加し, マスタース レーブ間の速度制御積分器にアンバランスが発生している が, 速度設定值到達時には, $e_{2}$ のオフセットは収束し, 直 流的なアンバランスが解消されている。また, 速度制御積 分器の最大詿差も 0.05 [p.u] 程度に抑えられている。さら に, 角度差 $e_{1}$ についても, 加速時に $e_{1}$ が発生するが, 速度 設定值到達時には, 直流的なオフセットが収束するように 制御され，最大角度差も \pm 3 [deg] 以内に抑えられている。 この比較結果より， $\gamma=0.3$ の場合には， $e_{2}$ が十分抑制さ れなかったために, 積分器のアンバランスに起因して $e_{1}$ の 直流分が発生しているが， $\gamma=31.25$ の場合には，積分器 のアンバランスに起因した角度差の発生が抑制されている 


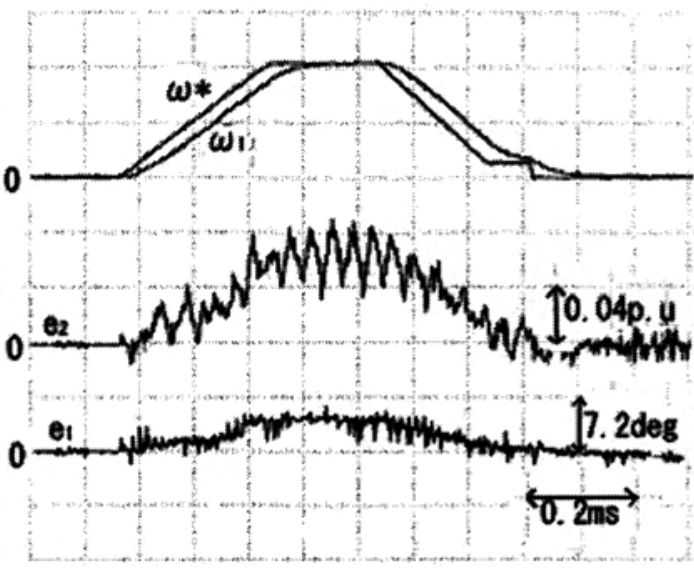

図 10 実験結果 $(\gamma=0.3)$

Fig. 10. Experimental result $(\gamma=0.3)$.

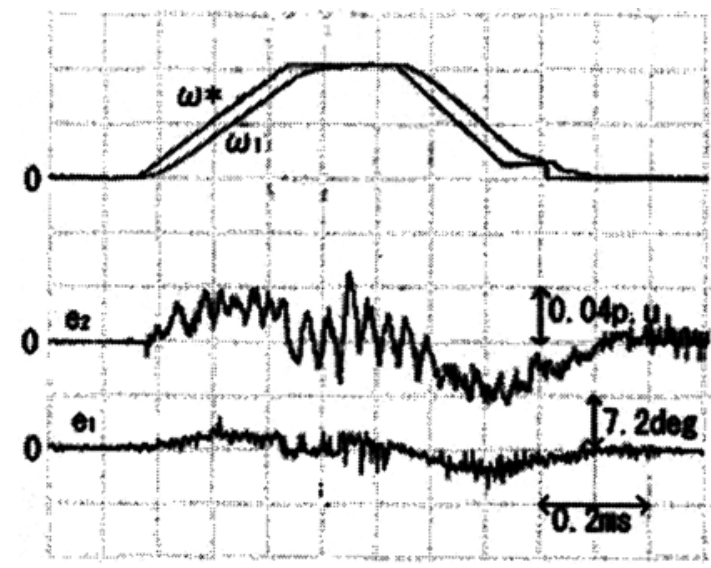

図 11 実験結果 $(\gamma=31.25)$

Fig. 11. Experimental result $(\gamma=31.25)$.

ものと考えられる。すなわち, 制御器 $K_{2}(=\gamma)$ を導入する ことによって, 角度差 $e_{1}$ が速度制御積分器のアンバランス $e_{2}$ の影響を受けることなく，制御されるという本制御方式 の有効性が示されている。

\section{5. まとめ}

本論文では，速度制御系をべースとした，マスタースレー ブ方式による同軸制御方法を提案し, 特に2つのサーボモー タとボールねじ駆動機構を有する射出装置をモデルとして 解析と実験を行い，本方式の有効性を示した。以下に要点 をまとめる。

（1）速度制御系をべースとしたマスタースレーブによ るサーボシステムに対し，可制御性の問題を明らか にすることによって，各軸の回転角度および速度制 御積分器の出力を追従させることが可能な制御方式 を提案した。

（2）提案した制御方式に対し，角度誤差と速度制御積 分器誤差に着目した解析を行い, 設計方法について 指針を示した。

（3）本制御方式によれば, 角度誤差と速度制御積分器誤
差を調整するパラメー夕は，ほぼ独立に調整でき，パ

ラメータ調整も容易であることを解析により示した。

（4）実際の射出装置により実験を行い，本方式の有効 性を確認した。

さらに, 今後の課題として, 本論文では, 2 軸の制御シス テムについて検討を行ったが，本方式はマスタースレーブ 方式であり, 基本的に複数軸への適用が可能な制御構造で ある。今後， 3 軸以上のシステムへの適用についても検討 を行いたい。また，本論文では，同軸制御アルゴリズムの 解析に重点を置いたため, 制御対象の非線形性については, 全て外乱トルク $\left(\tau_{L i}\right)$ に集約して解析を行った。今後の課 題として，外乱発生モデルの同定，外乱オブザーバ，状態 フィードバックを利用した特性改善，さらに 2 軸間の干渉 を考慮した解析に取り組んでいきたい。

サーボモータの用途が拡大し, 大容量化が進むにつれ, 複数軸による同期制御および同軸制御を行う用途が今後拡 大するものと思われる。本方式は，射出成形機だけでなく， 複数軸で高負荷を制御する他の用途に対しても有用な方式 であると考える。

(平成 16 年 12 月 27 日受付, 平成 17 年 7 月 6 日再受付)

\section{文献}

（1）井澤 實：ボールねじ応用技術, 工業調査会 (1993)

(2) N. Hur and K. Nam: "A Robust Load-Sharing Control Scheme for ParallelConnected Multisystems", IEEE Trans. On Industrial Electronics, Vol.47, No.4, pp. 871-879 (2000-8)

(3) M. Nakamura, D. Hiyamizu, and N. Kyura: "A Method for Precise Contour Control of Mechatronic Servo System with Master-Slave Axes by Use of Synchronous Position Control", Trans. of the Society of Instrument and Control Engineers, Vol.33, No.4, pp.274-279 (1997) (in Japanese)

中村政俊・冷水大作・久良修郭：「主軸中軸関係をもつメカトロサー ボ系の主軸位置同期を図った高精度輪郭制御法」, 計測自動制御学会 論文集, 第 33 巻, 4 号, pp.274-279 (1997)

(4) R. Nakashima, S. Kaku, H. Honda, R. Oguro, H. Miyakawa, and T. Tsuji: "The Position Control for Linear Slider with Twin Linear Drives", IEEJ Trans. IA, Vol.123, No.3, pp.278-285 (2003-3) (in Japanese)

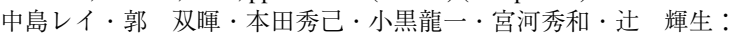
「ツインリニアドライブ機構を有するリニアスライダの位置決め制 御」, 電学論 D, 123, 3, pp.278-285 (2003-3)

(5) I. Godler: "Gain Tuning Method to Improve Sensor's Accuracy and Resolution", IEEJ Trans. IA, Vol.124, No.2, pp.196-201 (2004-2) (in Japanese) ゴドレール・イヴァン:「検出器の精度と分解能を改善するための ゲイン調整方法」, 電学論 D, 124, 2, pp.196-201 (2004-2)

(6) H. Nijmeijer: Alejandro Rodriguez-Angeles, Synchronization of Mechanical Systems, World Scientific (2003)

(7) K. Zhou, J.C. Doyle, and K. Glover: Robust and Optimal Control, PLENTICE HALL (1995)

\section{付 録}

1. (30) 式の導出

(26) 式，(27) 式，(29) 式より,

$$
\begin{aligned}
y_{1}-y_{2}= & \frac{s\left(\phi_{2}(s)-\alpha T s^{2}-\alpha s-\alpha \gamma+K_{I} \gamma\right)}{J \phi_{1}(s) \phi_{2}(s)} \tau_{L 1} \\
& -\frac{s\left(T s^{2}+s+\gamma\right)}{\phi_{2}(s)} \tau_{L 2} \ldots \ldots \ldots \ldots \ldots
\end{aligned}
$$

となる。一方, $\phi_{1}(s)$ と $\phi_{2}(s)$ の関係は, 


$$
\begin{aligned}
& J\left(T s^{2}+s+\gamma\right) \phi_{1}(s) \\
&= J\left(T s^{2}+s+\gamma\right)\left(s^{2}+\frac{K_{P}}{J} s+\frac{K_{I}}{J}\right) \\
&= J T s^{4}+\left(J+K_{P} T\right) s^{3}+\left(K_{I} T+K_{P}+J \gamma\right) s^{2} \\
&+\left(K_{I}+K_{P} \gamma\right) s+K_{I} \gamma \\
&= \phi_{2}(s)-\alpha\left(T s^{2}+s+\gamma\right)+K_{I} \gamma
\end{aligned}
$$

すなわち，

$$
\begin{aligned}
\phi_{2}(s)= & J \phi_{1}(s)\left(T s^{2}+s+\gamma\right) \\
& +\alpha\left(T s^{2}+s+\gamma\right)-K_{I} \gamma
\end{aligned}
$$

として得られるので，(付 2) 式を(付 1) 式に代入すると，

$$
\begin{aligned}
y_{1}-y_{2}= & \frac{s\left(T s^{2}+s+\gamma\right)}{\phi_{2}(s)} \tau_{L 1} \\
& -\frac{s\left(T s^{2}+s+\gamma\right)}{\phi_{2}(s)} \tau_{L 2}
\end{aligned}
$$

となる。得られた (付 3) 式を，(14) 式へ代入し，(30) 式を 得る。

\section{2. (31) 式の導出}

（26）式，(27)式，(28)式，(29) 式より，

$$
\begin{aligned}
e_{2} & =u_{1}-u_{2} \\
& =\frac{A_{1} \tau_{L 1}+A_{2} \tau_{L 2}}{J \phi_{1}(s) \phi_{2}(s)\left(T s^{2}+s+\gamma\right)}
\end{aligned}
$$

ここに，

$$
\begin{aligned}
A_{1}= & K_{I} \phi_{2}(s)\left(T s^{2}+s+\gamma\right) \\
& -\alpha K_{I}\left(T s^{2}+s\right)\left(T s^{2}+s+\gamma\right) \\
& +K_{I}^{2} \gamma\left(T s^{2}+s\right)-K_{I} \gamma \phi_{2}(s) \cdots \\
A_{2}= & K_{I} J\left(T s^{2}+s\right)\left(T s^{2}+s+\gamma\right) \phi_{1}(s)
\end{aligned}
$$

である。まず， $A_{1}$ について整理する。(付 5) 式第 4 項の $\phi_{2}(s)$ に，(付 2) 式を代入して整理すると,

$$
\begin{aligned}
K_{I} \gamma \phi_{2}(s)= & K_{I} J \gamma\left(T s^{2}+s+\gamma\right) \phi_{1}(s) \\
& +K_{I} \alpha \gamma\left(T s^{2}+s+\gamma\right)-K_{I}^{2} \gamma^{2}
\end{aligned}
$$

となる。これを式(付 5)に代入して整理すると，

$$
\begin{aligned}
A_{1}= & \left(T s^{2}+s+\gamma\right)\left(K_{I} \phi_{2}(s)-\alpha K_{I}\left(T s^{2}+s\right)\right. \\
& \left.-K_{I} J \gamma \phi_{1}(s)-K_{I} \alpha \gamma+K_{I}^{2} \gamma\right) \cdots \ldots .
\end{aligned}
$$

となる。さらに, 上式 (付 7) の $\phi_{2}(s)$ に, 再び (付 2) 式の 関係を代入して整理すると，

$$
A_{1}=\left(T s^{2}+s+\gamma\right)\left(T s^{2}+s\right) K_{I} J \phi_{1}(s)
$$

を得る。これより， $A_{1}$ についての (付 8 ) 式および， $A_{2}$ に ついての (付 6) 式を(付 4) 式に代入し，整理することによ り(31) 式を得る。

越 智 清 史 (正員) 1968 年生。1990 年 3 月東京電機大学理 工学部応用電子工学科卒業。同年 (株) 日本製鋼 所入社。2000 年 3 月広島大学大学院工学研究科 社会人博士前期課程システム工学専攻修了。現在

に至る。射出成形機の制御装置の開発に従事。

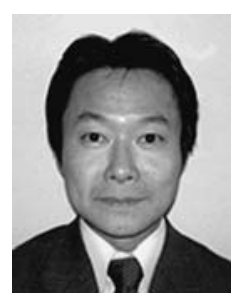

の会員。

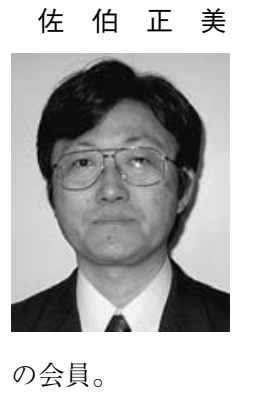

(正員) 1953 年生。1981 年京都大学大学院工学 研究科博士課程単位取得退学。同年京都大学工学 部助手。1982 年筑波大学電子 ·情報工学系講師, 助教授を経て, 1992 年広島大学工学部第一類教授 広島大学大学院工学研究科教授（制御工学担当） となり, 現在に至る。ロバスト制御系の設計の研 究に従事 (工学博士)。計測自動制御学会, シス テム・制御情報学会, 日本機械学会, IEEE など 